\title{
Public construction projects performance In Malaysia
}

\author{
Nurul Alifah Jatarona ${ }^{1}$, Aminah Md Yusof ${ }^{2}$, Syuhaida Ismail ${ }^{3}$ and \\ Chai Chaang Saar ${ }^{4}$ \\ ${ }^{1,2,4}$ Faculty of Civil Engineering, Universiti Technologi Malaysia \\ ${ }^{3}$ UTM Razak School, Universiti Teknologi Malaysia, Malaysia
}

Correspondence should be addressed to: Nurul Alifah Jatarona; alifah.kl@utm.my

Received date: 2 September 2015; Accepted date: 21 December 2015; Published date: 15 June 2016

Academic Editor: Ali Alashwal

Copyright (C 2016. Nurul Alifah Jatarona, Aminah Md Yusof, Syuhaida Ismail and Chai Chaang Saar. Distributed under Creative Commons CC-BY 4.0

\begin{abstract}
The performance level of the construction industry in Malaysia is seen as unsatisfactory, particularly in the construction of public projects. Public projects in Malaysia are regularly reported sick, delayed, abundant and etc. The persistent recurrences of similar problems in public construction projects have raised the public concern. Therefore, this paper takes the initiative to assess the problems encountered in the public project in Malaysia through document analysis. Based on the National Audit Reports, there are 69 problems identified in the public projects development. Upon the segmentation of early investigation, design, contract, construction and closing stage of construction tends to be the most problematic. As a result, particular attention should be given to ensure the accomplishment of time, quality and cost. Hence the attainment of value for money in public projects.
\end{abstract}

Keywords: Malaysia Construction industry; low performance factors;Malaysia Auditor Report.

\section{Introduction}

The Malaysian Government remains as the largest client in the construction industry. The government project or public project focusses mostly on the development of the basic infrastructure such as roads, dams, irrigation works, schools, houses, factories and other physical foundations on which development effort is poured in establishing the living standard of the public. Although a large allocation of national budget is used in the public development, some public projects are reported sick due to poor management. There are 235 sick projects discovered in 2011, 191 sick projects in 2013. The decrease of 20 percent in sick projects corresponds to increasing public construction budget from MYR504.5 billion to MYR550.6 billion in 2013. The Malaysian National Budget 2015 has allocated MYR770 billion in public projects, the results are hitherto unidentified. 
The general perception on the public construction project in Malaysian construction industry as a whole is underachieving. It has low profitability and does not invest enough in training, research and development. Limited trust, little cooperation, poor communication and an adversarial relationship are among the key problem areas experienced in the Malaysian construction industry (Yong and Mustaffa, 2012). Therefore, this paper is aiming to assess the problems in public construction projects in Malaysia via National Audit Report. Hence, discussion on the problems in construction is presented in detail in the following sections.

\section{Problems in the Construction Industry}

The success of a construction project is determined by completion time, budget, in_accordance with the specification and stakeholders' satisfaction. Functionality, profitability to contractors, absence of claims and court proceeding and "fitness for purpose" for occupiers have also been used as measures of project success (Majid, 2006). However, Chan and Chan (2004) define project success thing as different to different people. Each client, consultant, contractor, designer as well as sub contractor has their own interpretation in determining the success of a project. Chan and Chan (2004) further conclude that the definition of project success is depending on project type, size and sophistication, project participants and experience of owners, etc. However, in construction projects, reseachers agree that interpretation on the project success is merely based on the so called golden triangle namely time, cost and quality (Abdullah et al., 2010; Endut et al., 2005; Le-hoai et al., 2008; Majid, 2006; Ogunlana and Promkuntong, 1996; Othman et al., 2006; Sambasivan and Soon, 2007). Problems in construction highlighted in this paper are according to the aforementioned success factors.

Ogunlana and Promkuntong (1996) find three main problems namely problems of shortages or inadequacies in industry infrastructure (mainly supply of resources), problems caused by clients and consultants and problems caused by contractor incompetence/inadequacies in the construction of high rise building in Bangkok, Thailand. A Study in Vietnam construction industry found that poor site management and supervision, poor project management assistance, financial difficulties of owner, financial difficulties of contractor; design changes are five most frequent, severe and important causes of delays (Le-hoai et al., 2008). Ten most problematic factors are found by Sambasivan and Soon (2007) while assessing the delay causes and the effects in the Malaysian construction industry. Those problems are contractor's improper planning, contractor's poor site management, inadequate contractor experience, inadequate client's finance and payments for completed work, problems with subcontractors, shortage in material, labor supply, equipment availability and failure, lack of communication between parties, and mistakes during the construction stage. Furthermore, Abdullah et al., (2010) reveal that the significant delay causes in MARA (Majlis Amanah Rakyat) construction projects in Malaysia were cash flow and financial difficulties faced by contractors, contractors' poor site management and ineffective planning and scheduling by contractors. The above findings on the causes of delays are used as the basic factors in assessing the problems in public construction projects in Malaysia.

\section{Problems in Public Construction Projects in Malaysia}

The Malaysian government is committed to developing the national economy. Various transformations are introduced and implemented to ensure the success of Vision 2020, which was introduced by the Fourth Prime Minister of Malaysia, Tun Dr Mahathir bin Mohamad who focused on developing Malaysia and aimed for Malaysia to be a fully developed country by 2020. The legacy is continued by Datuk Seri Najib Tun Razak, the current Prime Minister by introducing the National Key Result Areas (NKRA), and the National Key Economic Areas (NKEAs). The NKRA is the government's effort to fulfil the public needs after the 2012 election. Through its six cores in the NKRA, thousands of projects have been designed and will be 
implemented in order to improve the quality of life of the public. The NKEAs represent economic sectors which account for significant contributions to Gross National Income (GNI). These comprise 12 National Key Economic Areas (NKEAs), representing sectors where growth will be focused on. These sectors were identified based on their potential to contribute to GNI and create multiplier effects across the economy. A total of 149 were projects announced under the NKEAs. Construction industry plays a major role in the initiatives introduced by the government. Many construction projects are planned involving the construction of infrastructure for the public and development projects that have potentials to contribute back to the Malaysia's economic. Therefore, the construction industry needs to move forward and makes itself in line with government initiatives.

Public construction projects in Malaysia are no exception in facing the problems as mentioned above. Many public projects are reported as not being completed on time, overrunning cost and not meeting specifications (CIDB, 2000 and CIDB, 2009). During project execution, functionality changes, thus this necessitates modifications to specifications and deliverables, which in turn lead to increase costs and delays (Pedrito and Marie-Louise, 2008). Increment in cost is considered by this paper as a crucial element in project success since cost overrun is one of the most important investment problems in developing countries. Since the outputs of public projects are used in almost all other sectors, project implementation failure affects the state of a country's economy which eventually leads to the misuse of the taxpayers' money.

According to the National Audit Report (2009), eleven public projects are reported as incomplete/non-complete, over budgeted, not meeting specification of the contract, not functionally suitable and not within the expected quality. Nine of the public projects experience delays, six are reported as not meeting specification and seven projects experience qualities issues. For example, public construction project for police housing and headquarter for
Kedah Contingent encounters problems such as delay, quality issue and not meeting the specification. The same problem faced in the public construction project of family flat for Army Mahkota Camp, Kluang, Johor Bahru (Chief Auditor Report, 2009). Recently, the scandalous issue that surprised the whole country was the Port Klang Free Zone project (PKFZ), another public construction project. Controversy began when the Malaysian Parliament's Public Accounts Committee met with the Port Klang Authority (PKA), because of the dissatisfaction with the huge cost overruns amounting to RM 3.5 billion (USD 1.0748 billion) associated with the Port Klang Free Zone (Chief Auditor Report, 2009). The original cost of setting up the integrated free zone was supposed to be RM1.845 billion but increased to RM4.6 billion when the project was completed four years later. Surprisingly, as these problems were highlighted by the National Audit Report (2009), similar problems were reported again by the National Audit Report (2010). Thus, appropriate action needs to be taken by the government considering that the projects encountered the same mistake for two consecutive years. The projects mentioned above serve as a reminder on the problem that public projects are facing. Furthermore, the same problems continue to occur in almost every public project. This signifies that Malaysia has not learnt any lesson from her past experience. The impact of these problems on Malaysian as well as taxpayers needs to be taken into consideration as eventually they are sufferring from the effect of the late delivery of the public projects.

\section{Research Methodology}

This paper utilized qualitative analysis in collecting, processing and analyzing the data collected. Content analysis is selected to meet these purposes. Content analysis is a reseach tool to determine the presence of certain keywords, concepts or set of texts in a document. Malaysia National Audit Reports are used to investigate the public construction problems in malaysia.

The National Audit Report is a report that presents financial statements, financial management and activities of the federal 
government and government enterprises. Enshrined in national constitutions in clauses 106 and 107, the Chief Auditor must submit the report to the King to get his consent before the report can be tabled in parliament. To meet this responsibility, the state audit department has conducted three types of audits such as the audit of the financial statements, compliance audits and performance audits. The purpose of the audit was to assess whether government activities are managed efficiently, economically and in line with the objectives of these activities. Recommendations made by the chief auditor are expected to be acted upon by the parties involved and also to prevent a recurrence of the same weaknesses.

In this paper, the data contained in this report have been used as the main data of the study. The data were collected in connection with the problems that occurred in specific construction projects involving building construction only. The building construction in general includes projects such as the construction of military camps, government staff housing, hospitals and many others. Reports of the auditor general for a period of 10 years starting from the year 2002 until the year 2012 have been downloaded from the official portal of the Malaysia state audit department.

\section{Results and Discussion}

The keywords in the findings of the causes of delays are used to identify the problems in Malaysian public construction projects. Moreover, whichever concepts or documents text that related to this issue are captured and documented. Each building construction project is examined in terms of the initial cost of the contract, the final cost of the contract, the start date and the end date, the initial construction period and the actual completion period and the factors contributing to the delay in the construction project. This process is done for all audit reports from 2003 to 2012. The weakness factors of building construction activity for government projects are collected. These factors are then examined and classified according to the phases and stages that contributed to the weakness in public construction projects in Malaysia. Figure 1 summarizes the problem factors in public construction projects in Malaysia. Poor performance in construction industry especially in public construction project has long been discussed. A number of suggestions for improvement has been made to Public Work Department (PWD) such as to prepare a proper planning for the projects, to identify the requirement of the user and the authority before starting the projects, to make sure instruction for amendment of work has been approved by the committee before starting works or before making the payment and to increase their supervision and monitoring works on site (Malaysia Audit Report, 2009; Malaysia Audit Report, 2010). However, these seem to be dead end as public project on the whole still has been reported as failed in meeting the Project Management Iron Triangle (time, cost and quality) and struggling with other issues such as late approval in giving the extension of time (EOT), incomplete specification and drawings and changes by owner during project execution (Malaysia Audit Report, 2009; Malaysia Audit Report, 2010).Currently very few studies have been done on the overall problem encountered by the public construction projects in Malaysia such as the study done by Yong \& Mustaffa (2012) on reexamining the factor of construction project in Malaysia, however their research focuses on the private sector. Other studies, focus more on problem related issues in construction industry in Malaysia such as delay (Kwang Sik Wei, 2010; Sambasivan and Soon, 2007), cost overrun and labour productivity (Kadir et al., 2005; Narayanan and Lai, 2005). The evidence from this preliminary results suggests that public construction projects in Malaysia do experience the underperforming issues. Therefore, this paper will serve as a base for future studies in addressing the low performance issues in public construction projects in Malaysia, focusing on the factors that lead to underachieving in the public projects in Malaysia. These identified factors serve as a reminder for the practioners in the Malaysian public construction projects as the critical factors that need to be focused and controlled as these factors may lead to bigger problem in construction industry specifically in Malaysia. 


\section{Conclusion}

Low performance issues such as delays, cost overrun and low quality in the public construction project are no longer accepted as per reports in the Malaysia Auditor Report from 2002 to 2012. Repetition of the same problem highlighted in the report indicates that there is no effort or study made in identifying the root cause of the problems faced by the public project and those problems will continue burdening the industry and affecting the quality of the public project. Therefore it is important to attempt those 69 low performance factors identified in the preliminaries study that are grouped into early investigation phase, design phase, contract phase, construction phase and upon closing phase before they are developed to be bigger and uncontrolled in the construction industry. The effect of low performance in construction will definitely affect the public as the end user. Facilities failed to be delivered on time and the low quality of the end product leads to anger of the public as they deserve better facilities with the tax money they paid. Angry public may lead to a serious picture as the public no longer trust the ability of the government in managing the country. This situation may lead to political and economic instability which ultimately will be the downfall of the current government. In avoiding these from happening, the government needs to overcome any issue that will affect their reputation. Therefore, by identifying the factors that affect the performance of the public construction projects, precaution actions can be made in handling those issues. Constructing facilities for the public always be in the Malaysia's government development plan in order to give better quality of life for the public. By removing issues in construction industry, it is not impossible for Malaysia to become a developed nation by 2020 as all the expenditure made in achieving the dreams is worth due to the government's good management. 


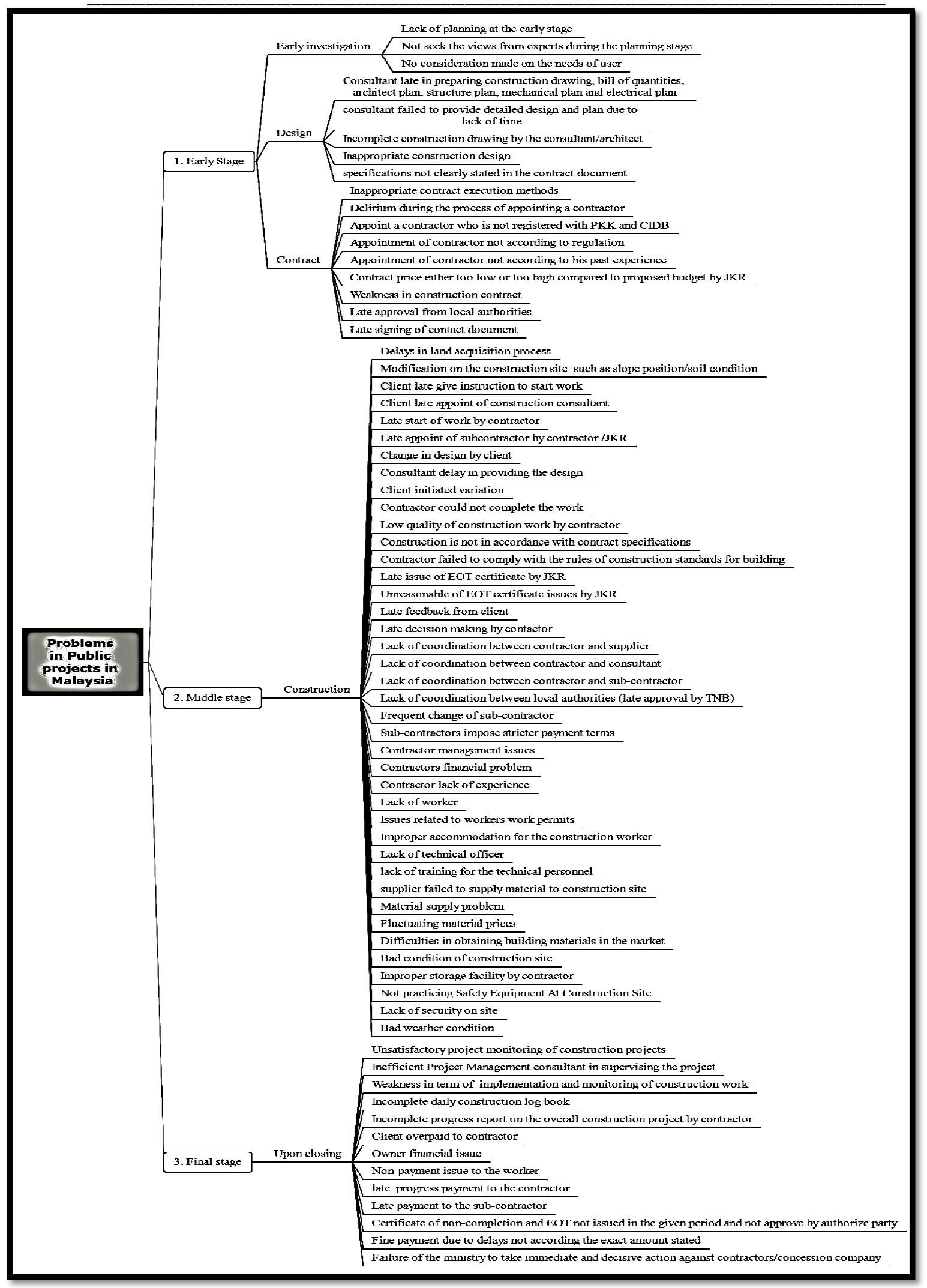

Figure 1: Problems classification according to phases in construction

Nurul Alifah Jatarona, Aminah Md Yusof, Syuhaida Ismail and Chai Chaang Saar (2016) , Journal of Southeast Asian Research, DOI:10.5171/2016.940838 


\section{References}

1. Abdullah, M. R., Rahman, I. A., Asmi, A., \& Azis, A. (2010). Causes of Delay in MARA Management Procurement Construction Projects. Journal of Surveying, Construction \& Property, 1(1), 123-138.

2. Chan, A. P. C., \& Chan, A. P. L. (2004). Key performance indicators for measuring construction success. Benchmarking: An International Journal, 11(2), 203-221. http://doi.org/10.1108/14635770410532 624

3. Endut, I. R., Akintoye, A., \& Kelly, J. (2005). Cost and Time Overruns of Projects in Malaysia. ICONDA Prooceedings of the 2nd Scottish Conference for Postgraduate Researchers of the Built and Natural Environment (PRoBE), (2001), 243-252.

4. Kadir, M. R. A., Lee, W. P., Jaafar, M. S., Sapuan, S. M., \& Ali, a. a. a. (2005). Factors affecting construction labour productivity for Malaysian residential projects. Structural Survey, 23(1), 42-54. http://doi.org/10.1108/02630800510586 90

5. Kwang Sik Wei. (2010). Causes, effects and methods of minimizing delays in construction projects kang sik wei universiti teknologi malaysia.

6. Le-hoai, L., Lee, Y. D., \& Lee, J. Y. (2008). Delay and Cost Overruns in Vietnam Large Construction Projects: A Comparison with Other Selected Countries, 12, 367-377. http://doi.org/10.1007/s12205-008-03677
7. Majid, I. A. (2006). Causes and effects of delays in Aceh Construction Industry. Universiti Teknologi Malaysia.

8. Narayanan, S., \& Lai, Y.-W. (2005). The Causes and Consequences of Immigrant Labour in the Construction Sector in Malaysia. International Migration, 43(5), 31-57. http://doi.org/10.1111/j.14682435.2005.00341.x

9. Ogunlana, S. O., \& Promkuntong, K. (1996). Construction delays in a fastgrowing economy: comparing Thailand with other economies, $14(1)$.

10.0thman, A. A., Torrance, J. V., \& Hamid, M. A. (2006). Emerald Article: Factors influencing the construction time of civil Factors influencing the construction time of civil engineering projects in Malaysia. http://doi.org/10.1108/09699980610690 756

11.Sambasivan, M., \& Soon, Y. W. (2007a). causes and effects of delays in Malaysia construction industry, 25, 517-526. http://doi.org/10.1016/j.ijproman.2006.1 1.007

12.Sambasivan, M., \& Soon, Y. W. (2007b). Causes and effects of delays in Malaysian construction industry. International Journal of Project Management, 25(5), 517-526. http://doi.org/10.1016/j.ijproman.2006.1 1.007

13.Yong, Y. C., \& Mustaffa, N. E. (2012). Analysis of factors critical to construction project success in Malaysia. Engineering, Construction and Architectural Management, 19(5), 543-556. http://doi.org/10.1108/09699981211259 612 